\title{
Føflekk eller malignt melanom?
}

\author{
Dermatoskopi er et viktig hjelpemiddel til å skille godartede føflekker fra malignt melanom. Leger bør bruke \\ dermatoskop når pigmenterte lesjoner hos personer med forhøyet risiko for melanom skal vurderes.
}

Malignt melanom kan ramme personer $i$ alle aldre. Hos voksne under 50 år er dette den nest hyppigste kreftformen i Norge (1). Muligheten for å overleve sykdommen er i høy grad avhengig av diagnosetidspunkt. Ved melanom i stadium 1 er femårsoverlevelsen opptil $97 \%$, mens den i stadium 3 i beste fall er opptil $78 \%$ (2). Et påvist melanom utgjør en høy risiko for at et nytt primært melanom kan oppstå senere. Mens faren for residiv gradvis avtar etter gjennomgått behandling, ser risikoen for et nytt primært melanom ut til å være konstant forhøyet i opptil 20 år (3).

\section{Betydningen av dermatoskopi}

Melanomer kan likne på godartede nævi. Når føflekker eller andre pigmenterte lesjoner ikke sikkert lar seg klassifisere

\section{Nye retningslinjer for malignt melanom}

Helsedirektoratet har nylig gitt ut en revidert utgave av det norske handlingsprogrammet for malignt melanom (8). Ifølge de nye retningslinjene kan pasienter med malignt melanom som har gjennomgått kurativ behandling, i de fleste tilfeller kontrolleres hos allmennlege. Dersom det foreligger ytterligere risikofaktorer, slik som dysplastiske nævi eller melanom i nær familie, anbefales kontroll hos hudlege (8).

Vi mener dette skillet er problematisk. Det innebærer at en betydelig andel av melanompasientene ikke får oppfølging med dermatoskopi. I dag er det bare pasienter som følges opp av hudlege som i praksis blir undersøkt på denne måten. I Australia, som har verdens høyeste fore-

\section{«Dersom allmennleger skal kunne benytte seg av dermatoskop, må det satses på målrettet videreutdanning, slik man har gjort i Australia»}

klinisk, må de fjernes (eller biopseres) for histologisk undersøkelse. Ikke alle suspekte lesjoner viser seg å være melanom, slik at man fjerner et visst antall nævi «unødvendig» for ikke å overse et melanom.

Hudleger benytter rutinemessig dermatoskop for lettere å kunne vurdere mistenkelige forandringer, men metoden benyttes så langt $i$ liten grad av allmennleger. Nytten av dermatoskopi er dokumentert i flere studier $(4,5)$. En metaanalyse viste en signifikant økning i sensitiviteten fra $71 \%$ til $90 \%$ ved bruk av dette diagnosesverktøyet. Spesifisiteten var $90 \%$ ved dermatoskopi mot $81 \%$ uten, men denne forskjellen var ikke statistisk signifikant (5).

Dermatoskopi kan også redusere antallet godartede nævi som fjernes (6). I en svensk studie var de beregnede kostnadene per diagnostisert melanom lavere når hudavdelinger sto for diagnostikken av nævi og melanomer sammenliknet med andre avdelinger og primærhelsetjenesten (7). Dette ble forklart med at hudspesialister gjennom sin erfaring og ved å bruke dermatoskop fjernet færre godartede nævi. komst av melanom, anbefales det at alle leger som regelmessig vurderer pigmentforandringer bruker dermatoskop (9), og mange australske allmennleger har lært seg dermatoskopi (H.P. Soyer, The University of Queensland, personlig meddelelse).

Vi kjenner ikke til noe kurs i Norge som har som målsetting å lære allmennleger dermatoskopi. Dersom allmennleger skal kunne benytte seg av dermatoskop, må det satses på målrettet videreutdanning, slik man har gjort i Australia (10). Siden forekomsten av melanom i Norge er betydelig lavere enn i Australia, er det usikkert om allmennleger i Norge har muligheten å tilegne seg tilstrekkelig praktisk erfaring.

Vi mener at dermatoskopi må bli et standard diagnoseverktøy som alle melanompasienter bør få nytte av ved kontrollundersøkelser. Det bør utvikles kurstilbud for allmennleger som følger opp melanompasienter. Allmennleger og hudleger bør utvikle et systematisk samarbeid for at alle melanompasienter blir undersøkt jevnlig med dermatoskopi.
Thomas Schopf

thomas.roger.schopf@telemed.no

Nasjonalt senter for samhandling og telemedisin Universitetssykehuset Nord-Norge

\section{Jürgen Funk}

Dr. Funk's Hudklinikk

Moss

Thomas Schopf (f. 1969) er spesialist i hud- og veneriske sykdommer, ph.d.-kandidat og rådgiver ved Nasjonalt senter for samhandling og telemedisin, Universitetssykehuset Nord-Norge. Forfatter har fylt ut ICMJE-skjemaet og oppgir ingen interessekonflikter.

Jürgen Funk (f. 1960) er spesialist i hud- og veneriske sykdommer og avtalespesialist i Moss med lang erfaring i behandling av hudkreft. Forfatter har fylt ut ICMJE-skjemaet og oppgir ingen interessekonflikter.

\section{Litteratur}

1. Cancer in Norway 2009. Cancer incidence, mortality, survival and prevalence in Norway. Oslo: Kreftregisteret, 2011.

2. Balch CM, Gershenwald JE, Soong $S$ et al. Final version of 2009 AJCC melanoma staging and classification. J Clin Oncol 2009; 27: 6199-206.

3. McCaul K, Fritschi L, Baade P et al. The incidence of second primary invasive melanoma in Queensland, 1982-2003. Cancer Causes Control 2008; 19 451-8.

4. Kittler H, Pehamberger $\mathrm{H}$, Wolff K et al. Diagnostic accuracy of dermoscopy. Lancet Oncol 2002; 3 : $159-65$.

5. Vestergaard ME, Macaskill P. Holt PE et al. Dermoscopy compared with naked eye examination for the diagnosis of primary melanoma: a metaanalysis of studies performed in a clinical setting. Br J Dermatol 2008; 159: 669-76.

6. Carli P. De Giorgi V, Crocetti E et al. Improvement of malignant/benign ratio in excised melanocytic lesions in the 'dermoscopy era': a retrospective study 1997-2001. Br J Dermatol 2004; 150: 687-92.

7. Lindelöf B, Hedblad MA, Ringborg U. Nevus eller malignt melanom? Rätt kompetens vid diagnostik ger lägre kostnader. Läkartidningen 2008; 105 2666-9.

8. Nasjonalt handlingsprogram med retningslinjer for diagnostikk, behandling og oppfølging av maligne melanomer. Oslo: Helsedirektoratet, 2011.

9. Clinical practice guidelines for the management of melanoma in Australia and New Zealand. Wellington: The Cancer Council Australia/Australian Cancer Network/Ministry of Health New Zealand, 2008

10. Australasian College of Skin Cancer Medicine. www.skincancercollege.com/Home.aspx (8.12.2011).

Mottatt 27.12. 2011 og godkjent 15.1.2012. Medisinsk redaktør Petter Gjersvik. 